\title{
Panopticon - cybercontrol in liquid modernity: what does control really mean in contemporary management?
}

\author{
Roman Batko ${ }^{1, *}$ \\ ${ }^{1}$ Jagiellonian University, Krakow, Poland \\ E-Mail: roman.batko@uj.edu.pl (R.B) \\ * Author to whom correspondence should be addressed;
}

Accepted: March 3, 2015

The paper proposes a critical analysis of the panopticon, the model of an ideal prison devised in the 18th century by the English philosopher Jeremy Bentham, and its function in modern management. The original prison was designed in such a way that it enabled a single prison guard to watch all the inmates at all times, while the latter could never tell whether they were currently being watched or not. The idea behind the panopticon gave rise to the concept of panopticism, a philosophy developed by the French thinker Michel Foucault, which he voiced in Discipline \& Punish: The Birth of the Prison (1975/1995). Analyzing the mechanism of control through the ages, he ponders the resilience and adaptability of such concepts as discipline, training and hierarchical surveillance. According to Foucault, man is held captive by the control machine equipped with an apparatus for observation, recording and training. Today these very concepts, if slightly euphemized, constitute the cornerstone of scientific management. I intend to provide a critical analysis of the modern methods and techniques of control, which more often than not is executed nowadays by surveillance equipment and computer programs; hence my term of choice - "cybercontrol". In the presentation of the results of my qualitative research conducted at selected organizations I am going to rely on the conceptual apparatus of Critical Management Study (Alvesson, Willmott 1992, 2003). Exercising control is one of the fundamental functions of management. Organizational structures, processes, and rules enable managers to control the chaos which could otherwise easily substitute cooperation. Over the recent decades, however, the control mechanisms have escalated beyond any reasonable proportions, becoming the modern embodiment of the original panopticon (Taylor, 2015). There is a growing tendency to 
monitor all employee activity (including non-work-related behavior) by means of oppressive calculating equipment which records every computer click, every second of a telephone conversation, and the exact time spent away from one's desk. Some companies take the control issue further still, introducing elements which can only be described as a prelude to total control: for instance, the Swedish firm Epicenter makes its employees wear microchip implants equipped with a radio locator, which - according to the company's rhetoric - are to better safeguard their privacy. Last but not least, there are the global internet services and networks, such as Google, Facebook and numerous others, which exercise control over billions of users, gathering personal information about their age, gender and interests, and are even able to trace, by means of the GPS system, their exact location. The services also record all search histories, e-mails, calendars, photographs and other files which become, in fact, indelible traces billions of people leave behind on servers, for anyone to use and abuse. The inevitable question is, is the brave new project such as the Global Brain, with its attributes of omniscience, omnipresence, omnipotence (Heylighen, 2014), yet another tool encouraging omnipotent control? And is not the struggle man today undertakes - raging, in the name of reclaiming his freedom, against the machine, our desperate attempt to save the virtues of humanism in the face of the imminent mutation of man into the cyborg?

\section{Bibliography:}

1. Alvesson, M., \& Willmott, H. (Eds.). (1992). Critical Management Studies. London; Newbury Park: SAGE Publications Ltd.

2. Alvesson, M., \& Willmott, H. (Eds.). (2003). Studying Management Critically. London; Thousand Oaks, Calif.: SAGE Publications Ltd.

3. Foucault, M. (1995). Discipline \& Punish: The Birth of the Prison. New York: Vintage Books.

Heylighen, F. (2013). Return to Eden? Promises and Perils on the Road to a Global Superintelligence. In B. Goertzel \& T. Goertzel (Eds.), The End of the Beginning: Life, Society and Economy on the Brink of the Singularity. Retrieved from http://pespmc1.vub.ac.be/Papers/BrinkofSingularity.pdf

Taylor, S. S. (2015). "Controls and Constraints". Organizational Aesthetics, 4(1), 1-3. 